\title{
Spiritual-Based Transformational Leadership Style at Anutapura Regional General Hospital, Palu
}

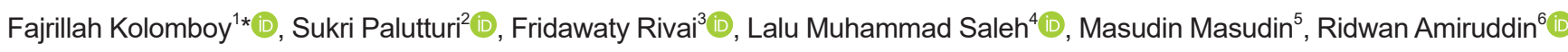 \\ ${ }^{1}$ Doctoral Student of Public Health, Universitas Hasanuddin, Makassar, Indonesia; ${ }^{2}$ Department of Health Policy and \\ Administration, Faculty of Public Health, Universitas Hasanuddin, Makassar, Indonesia; ${ }^{3}$ Department of Hospital Administration \\ Management, Faculty of Public Health, Universitas Hasanuddin, Makassar, Indonesia; ${ }^{4}$ Department of Occupational Health and \\ Safety, Faculty of Public Health, Universitas Hasanuddin, Makassar, Indonesia; ${ }^{5}$ Department of Nursing, Poltekkes Kemenkes \\ Palu, Palu, Indonesia; ${ }^{6}$ Department of Epidemiology, Faculty of Public Health, Hasanuddin University, Makassar, Indonesia
}

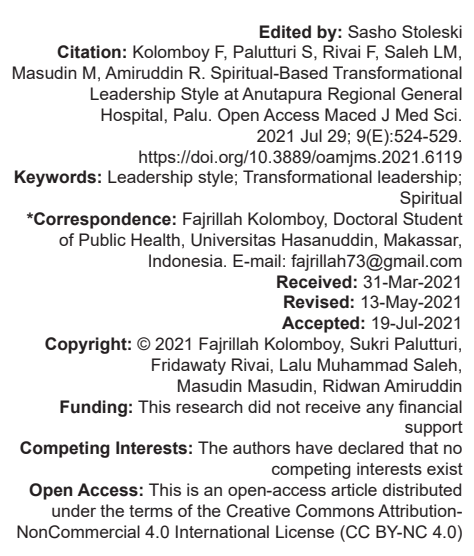

Introduction

Patient safety is a global health problem and is a very complex health issue involving many parties [1], [2]. Each year, there are 134 million cases which contribute to the 2.6 million deaths that occur in low and middle-income countries. In addition, the failure of patient safety measures occurs about $15 \%$ of spending the hospital costs [3].

Research conducted by Casida and Pinto concluded that one of the factors affecting the implementation of patient safety measures is the leadership style of the head of the ward who is responsible for the safety culture in the unit or treatment ward [4]. In the process, leaders have different leadership styles including using transformational leadership styles and spiritual leadership [5]. Transformational leadership is a relationship between leaders and their followers in which both parties are elevated to a higher moral level [6]. The results of studies using the pathway analysis method stated that transformational leadership is an important factor in building a patient safety culture and has a positive effect on patient safety culture and patient safety outcomes [7]. Meanwhile, Spiritual leadership is a developing paradigm designed to provide intrinsic motivation to help transform an organization, where a leader brings the worldly dimension to the spiritual dimension [8].

However, the essence of transformational leadership and spiritual leadership is still not applied by every leader in an organization. Spiritual-based transformational leadership is the combination of indicators of transformational leadership with spiritual leadership which is thought to create a trans-spiritual leadership style that has an effect on patient safety culture. Spiritual leadership in the field of nursing is relatively poorly studied, due to contextual factors such as social culture and pluralism, whereas a spiritually conducive environment has a positive impact on patients, nurses, and organizations. This is the urgency in our research because to foster a culture of patient safety, leaders who have personality qualities, religious ethics, and spiritual values are needed to lead. A leader figure is 
expected to be able to inspire, generate, influence, and move through exemplary, love, and other divine qualities. Therefore, the researcher considered that there must be an alternative solution to overcome it. Researchers considered it necessary to offer a theoretical solution to the development of a trans-spiritual leadership model because its advantages lie in combining transformational leadership indicators with spiritual leadership and organizational culture which is thought to create a transspiritual leadership style so that it affects the patient safety culture. Perceptions of patient safety, cooperation within and between units, have not been maximal [9]. Building a patient safety culture in the hospital is the obligation and responsibility of all parties by involving all components of health workers, especially nurses who have the longest contact time with patients through the leadership role of the head of the room who has a vital role through a spiritual and organizational culturebased transformational leadership model development approach. In shaping a culture of patient safety [10].

This study aimed to examine the spiritualbased transformational leadership style at Anutapura Regional General Hospital, Palu.

\section{Methods}

This study used a qualitative method with a hermeneutical phenomenology approach. Researchers conducted focus group discussion (FGD) and in-depth interviews with all participants.- There were 12 informants, namely, key informants from top management elements (two people), main informants, namely, Executing Nurses, Head of Division (four people), supporting informants from Islamic/Christian/Hindu religious figures (three people), community leaders (one person), PPNI professional organization (two people). Selection of informant subjects using purposive sampling as a source of data in this study with the criteria of mastering the problem, having data, domiciled in Palu and its surroundings, and willing to provide complete and accurate information. The researcher conducted an FGD for all participants which were conducted from August to December 2020. The list of FGD questions is shown in Table 1.

Data analysis uses $\mathrm{N}$ Vivo through a coding draft mechanism, coding reduction, determining subthemes and themes which will later be used as indicators or additional dimensions (sub variables) in the study.

\section{Results}

Based on the results of data analysis using NVIVO software, there were 3 themes related to

\section{Table 1: List of Questions for FGD}

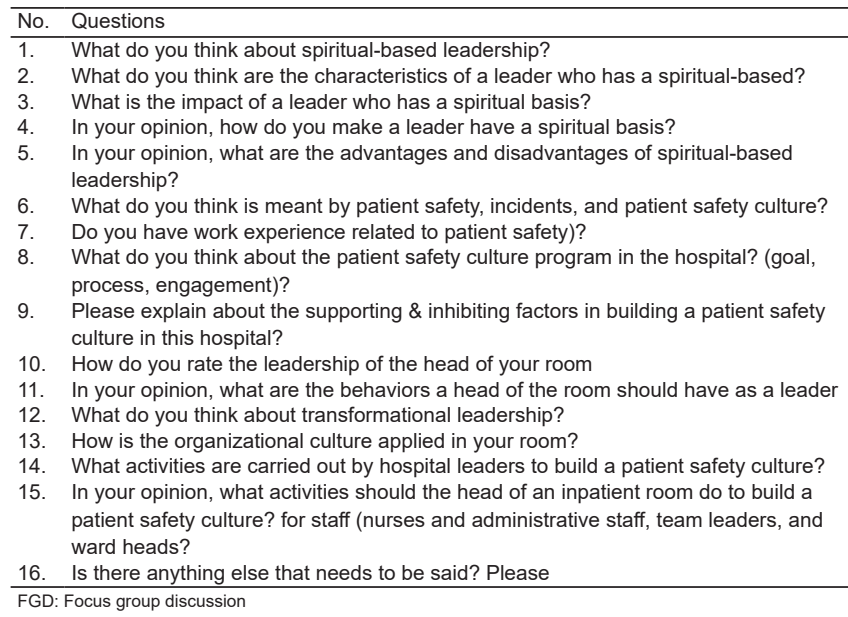

spiritual-based transformational leadership in this study, those are; (1) emotional skills, (2) spiritual skills, and (3) social skills. The data analysis process led to each question that was used as a reference for the FGD, based on the sub-themes that are suitable by using NVIVO, including:

\section{Informants' perceptions on emotional} skills

The first perception is related to emotional skills. The participants, consisting of health workers, religious leaders, and community leaders, have expressed their opinions about emotional skills. The two sub-themes obtained are emotional skills and emotional intelligence.

The results of this study indicate that the group of informants in the discussion group described one of the characteristics of a spiritual-based transformational leader, namely, having emotional skills including the ability to provide motivation and inspiration; be a role model, role model, and committed; have an attitude of empathy and sympathy; respond to conflict management and be able to be a motivator; able to work in teams, have good skills and obey the rules. Among the informants' statements were expressed as follows:

"the leader is able to motivate and lead the patient later to avoid injury. That is the first then the second that always inspires both his patients and his fellow workers. So motivation, give inspiration. When he motivates him, he raises the patient's enthusiasm, for example, now it's not just patient safety, everyone's safety, people don't want to wear masks " (Professional Organization (P1)).

"......motivation and encouragement so that the situation of the leader and those who are led is well intertwined" (Religious group (P1)). "The head of the room can be an inspiration to the nurse in our room so that we have daily actions that can become their role model. The leader is a role model so he must have caring, 
sympathy and empathy for the patient" (Head of Division).

"...Indeed, there must be exemplary and commitment from the leader. Then in addition to caring that is also added is empathy so that we can feel what other people feel. Able to respond to conflict management in an organization they lead" (Nurse group).

"That skill is definitely a must-have. Good skill ...." (Head of Division)

"........what is important is trust and commitment" (community leaders).

The first sub-theme is emotional skills. Eight informants gave perceptions about emotional skills including the Executing Nurses, Head of Division, Professional Organization, and community leaders. The 8 informants argued that the emotional skills that must be possessed in a spiritual-based transformational leadership style consist of five parts, in which the leader must have empathy and sympathy, be able to be a mediator and have the capacity in conflict management, be able to be role models, as well as commit, provide motivation and inspiration to the environment. Finally, the leader must also be able to work in a team, have good skills, and comply with the applicable rules.

The informant group said it is important for a leader to have an Emotional Quotient (EQ) with the characteristics of being able to realize and manage one's own emotions, having sensitivity to the emotions of others, being able to respond and negotiate with others emotionally, and being able to use emotions as a tool to motivate oneself. The informants' statements were as follows:

"A spiritual-based leadership style is closely related to a leadership style that upholds the values of belief, has a sense of density or high sensitivity in leading. A leader is not only able to mobilize but must lead based on religious ethics and be able to control emotions. So a leader must not only have an Emotional Quotient but must have an Emotional and Spiritual Quotient" (Executing Nurses).

\section{Informants' perceptions on spiritual skills}

The second perception is related to spiritual skills. The participants who are health workers, religious leaders, professional organizations, and community leaders have expressed their opinions about emotional skills. There are two sub-themes obtained including the spiritual attitude and spiritual intelligence.

The first sub-theme is spiritual attitude. Seven informants gave perceptions about spiritual attitudes including the executing nurses, Head of Ward/Head of Division, religious leaders, professional organizations, and community leaders. The seven informants gave the perception that a leader with a spiritual-based transformational leadership style must uphold the values of belief, always involve God in every activity, believe in all values of worship and work as a field of charity, have good morals and attitudes, and be a leader who can carry out responsibilities.

The results showed that the group of informants characterized a leader who believed that all activities had religious values and made work as a field of charity; trustworthy leaders so as to create a sense of security; good character and attitude; uphold the value of belief and present God in every activity. Among the informants' statements were expressed as follows:

"what he does he believes is the value of worship so the orientation is charity. There is worship and there is charity, so if later orientation is charity, then that motivation drives doing something. The head of the room, especially as a nurse, stated that helping someone is very valuable in the eyes of Allah SWT" (Professional Organizations (P2)).

"....In carrying out its activities, there is God who always sees and whatever is done is always of worship value. Whatever he does forever is solely because of the value of worship that we do both to ourselves and to others. Everything he does is there God is there, God is there whatever he moves. Wherever his footsteps, then his thoughts, feelings and others are inspired or believed that there is God there, there is God there, his spiritual approach is trustworthy leadership. The Prophet said that someone does not believe if he does not have a mandate, so that one indicator of that person is believing if he is carrying out the mandate" (Religious Leaders (P2)).

"...focuses on worship so that worldliness leads to the spiritual hereafter. Have a good attitude so that serving patients is done sincerely" (Head of Division)

Meanwhile, the second sub-theme is spiritual intelligence. Five informants provided perceptions about spiritual intelligence, including professional organizations, Head of Ward/Head of Field, and community leaders. The five informants argued that in addition to the value of $E Q$, leaders with a spiritual-based transformational leadership style must have $S Q$ values (flexible, adaptable, have a high level of awareness, able to take lessons from failure, live according to the vision and mission, and independent).

The informant group stated the importance of a leader having a Spiritual Quotient (SQ) with the characteristics of being flexible, adaptable, having a high level of awareness, being able to take lessons from a failure, living according to the vision and mission, and being independent. The informants' statements were as follows:

"...there is already belief or hope. Spiritual leadership has a clear vision and mission" (Head of Field). 
".....have a clear, strong spiritual vision that is also visible in leading and sticking to the rules that apply" (Executing Nurses).

".......believe in his spiritual abilities"(community leaders)

\section{Informants' perceptions on social skills}

The third perception is related to social skills. The participants consisting of health workers, religious leaders, professional organizations, and community leaders have expressed their opinions on spiritual skills. There is one sub-theme obtained which is the ability to socialize.

The informant stated that the leader must have honesty, be patient and be kind with prejudice; has caring properties; using bio, psycho, social, spiritual approaches; protect the rights of others, be responsible; have concern, make wise decisions; give a positive touch; and understanding basic human needs (Abraham Maslow's theory). These characteristics are summarized as the ability to be social. Among the informants' statements were expressed as follows:

"......there must be a dimension of patience in it. Leaders must be patient. Then be kind. The leader must understand human beings as a whole in a biosocial-spiritual health approach" (Professional Organizations (P1)).

".......the honest leader creates a safe situation. So when transformational leadership is connected with spiritual I think the most important thing is honesty. Honesty is the key, a leader really has to be honest, then when it comes to cultural and health transformation, there are 8 categories of leadership, one of which is simply indrabrata with a very good biopsychosocial approach. Biological, Psychological and Sociological Approaches in the context of transformational leadership so as to protect and protect the rights of others" (Religious Leaders (P2)).

"Spiritual leadership besides having a clear vision and mission, has hope, love, honesty and empathy. Caring has a presence both physically and in communicating, in direct contact and eye contact. There is a value about morality. Responsible to the hereafter not only to friends in the hospital" (Executing Nurses).

"The truth is honesty, if a leader cannot be honest, what about the others?" (Head of Ward/Head of Division)

In this sub-theme, ten informants provided perceptions about the leader's ability to behave socially including the executing nurse, Head of Ward/Head of Division, Religious Leaders, professional organizations, and community leaders. The ten informants argued that a spiritual-based transformational leadership style must also include aspects of society including caring, wise in making decisions; honest, patience and kindness; respecting others' rights, be responsible; affects positively; understand the basic human needs (Abraham Maslow's theory); and use bio, psycho, social, and spiritual approaches in interacting with others.

The results of qualitative data analysis with the NVIVO 12 plus program summarize the results of coding, sub-themes, and themes in the percentage coverage presented in Table 2:

Table 2: Analysis of the themes and sub-themes of the FGD results related to spiritual-based spiritual leadership

\begin{tabular}{|c|c|c|}
\hline Coding & $\begin{array}{l}\text { Coverage } \\
(\%)\end{array}$ & Subthemes \\
\hline \multicolumn{3}{|l|}{ Emotional skills } \\
\hline 1. Provide motivation and inspiration & 10.42 & Emotional prowess \\
\hline $\begin{array}{l}\text { 2. Able to be a role model, role model, and } \\
\text { commitment }\end{array}$ & 6.24 & \\
\hline 3. Have empathy and sympathy & 5.21 & \\
\hline $\begin{array}{l}\text { 4. Handle conflict management, become a } \\
\text { mediator }\end{array}$ & 4.16 & \\
\hline $\begin{array}{l}\text { 5. Able to work in teams, have good skills, obey } \\
\text { the rules }\end{array}$ & 2.08 & \\
\hline $\begin{array}{l}\text { 6. Have EQ (able to realize and manage one's } \\
\text { own emotions, have sensitivity to other } \\
\text { people's emotions, be able to respond and } \\
\text { negotiate with others emotionally, and can use } \\
\text { emotions as a tool to motivate oneself) }\end{array}$ & 6.24 & Emotional intelligence \\
\hline \multicolumn{3}{|l|}{ Spiritual skills } \\
\hline $\begin{array}{l}1 \text { Believing in all values of worship, Working as a } \\
\text { field of charity }\end{array}$ & 10.96 & Spiritual attitude \\
\hline $\begin{array}{l}\text { 2. A trustworthy leader that creates a sense of } \\
\text { security }\end{array}$ & 3.12 & \\
\hline 3. Good character, good attitude & 1.04 & \\
\hline 4. Upholding the values of trust & 1.04 & \\
\hline 5. Presenting Allah in every activity & 1.04 & \\
\hline $\begin{array}{l}\text { 6. Have SQ (flexible, adaptable, have a high } \\
\text { level of awareness, able to take lessons from a } \\
\text { failure, live according to the vision and mission, } \\
\text { be independent) }\end{array}$ & 7.83 & Spiritual intelligence \\
\hline \multicolumn{3}{|l|}{ Social skills } \\
\hline 1. Have honesty, be patient and kind & 22.92 & Able to be social \\
\hline 2. Have caring & 6.25 & \\
\hline 3. Using a bio, psycho, social, spiritual approach & 5.21 & \\
\hline 4. Safeguard other people's rights, be responsible & 4.17 & \\
\hline 5. Have caring, make wise decisions & 4.16 & \\
\hline 6. Give a positive touch & 3.12 & \\
\hline $\begin{array}{l}\text { 7. Understanding basic human needs (Abraham } \\
\text { Maslow's theory) }\end{array}$ & 1.04 & \\
\hline
\end{tabular}

Table 2 shows that a spiritual-based transformational leader needs to have three main skills, namely emotional skills, spiritual skills, and social skills.

\section{Discussion}

A factor which affects the adoption of patient safety measures is the managerial leadership style. In this context, the role of a leader who moves the organization into the future must recognize environmental needs and facilitate appropriate change to become clearer. Such leaders are called transformational leaders. These leaders can strengthen staffs' understanding and fairness and improve the quality of work-life in the organization. The quality of work-life includes the enhancement of organizational culture which increases the employees' satisfaction which leads to their development and growth in the 
organization [11]. Transformational leadership styles have a direct and positive effect on managerial performance. Transformational leadership styles can rely on decision influence and decision facilitation to improve the employees' performance [12]. In health care, transformational leadership is found to be associated with job satisfaction of hospital nurses positively affecting overall job satisfaction, both intrinsic or extrinsic [13].

\section{Emotional skills}

Emotional skills in spiritual-based transformational leadership are defined as the leader's ability to understand and manage the emotions that exist within him and recognize and influence the emotions of those around him. Emotional intelligence (EQ) is a set of important skills in leadership covering how leaders perceive and express themselves, develop and maintain social relationships, overcome challenges, and use emotional information in effective and meaningful ways [14].

Leaders who have developed skills related to emotional intelligence using their moods and emotions or the emotions of others to motivate others to display the desired behavior can be said that the leader has succeeded in facilitating change [15]. Emotional intelligence is the most important element that contributes to enhancing morale, cooperation, teamwork, motivation, and a positive work environment [15].

\section{Spiritual skills}

One of the transformational leadership styles is spiritually-based. Spirituality is required in a sustainable workplace for employees' ethical attitudes, life, job satisfaction and commitment, employees' productivity, and organizational performance. The benefits of spirituality at work through spiritual leadership have an impact on employees' organizational behavior, which is characterized by awareness of a higher purpose, sense of meaning at work, engaging in job responsibilities and ethical decisions, and ultimately becoming part of society [16].

The head nurse in the hospital always tries to have a good relationship and increase cooperation with the other individuals in the Hospital [17], [18]. For this reason, as a head nurse, he must have the ability to control his emotions. Good emotional skills at work can improve the quality of care [19]. Emotional intelligence is a charismatic virtue for nurse leaders, which overcomes chronic challenges in nursing practice, thus it must be implemented well [20].

Spiritual-based transformational leadership has a significant relationship to patient safety culture at Anutapura Hospital, Palu. Leadership style is key to fostering a patient safety culture [21], [22]. Therefore, the leadership style, communication techniques, and managerial skills of leaders need to be considered in creating a conducive work atmosphere as an effort to create a patient safety culture [23].

Spiritual leaders in nursing can achieve organizational goals by paying attention to the extrinsic and intrinsic motivational elements of the personnel. Spiritual skills can foster a sense of God-consciousness, and the need for social relationships or membership in organizations [24].

\section{Social Skill}

Social skills in spiritual-based transformational leadership are defined as the ability of leaders to create social processes to influence, motivate, and allow others to contribute to organizational effectiveness and success. Socially skilled leaders can easily adapt to managing a team [25]. Social skills have connotations that are closely related to social competence and social intelligence. In essence, social intelligence uses awareness of the substantial impact of relationships to help leaders improve the performance of those they lead. Personal skills such as initiative, empathy, adaptability, and persuasiveness are essential as leadership tools. Lack of awareness of the emotional impact on others can make a leader fail as a manager, regardless of how competent he or she is in science or job skills [26].

Furthermore, social skills are also related to the spiritual-based transformational leadership style in this study, where doctors and nurses rely heavily on the head nurse to communicate, give advice, and know the treatment activities. The head nurse plays an important role in assisting communication between staffs. This suggests that social skills are a useful approach for communication [27].

The limitation of this research is that FGD with informants is conducted online (zoom meeting) so that expressions, behavior, and communication are sometimes hampered due to signal, network disturbances.

\section{Conclusion}

The spiritual-based transformational leadership style is related to three skills, which are emotional, spiritual, and social skills. A spiritual-based transformational leadership style can create a conducive work atmosphere as an effort to create a culture of patient safety. 


\section{References}

1. Indar I, Nurhayani N, Amir MY, Darmawansyah D, Palutturi S, Hernadi H. Legal aspects of emergency medical services department of wahidin sudirohusodo hospital, Makassar Indonesia. Indian J Public Health Res Dev. 2018;9:16-20. https://doi.org/10.5958/0976-5506.2018.00406.0

2. Armin A, Maidin A, Sidin I, Rivai F, Palutturi S. Patient satisfaction based on Bugis philosophy at the Siwa hospital in Wajo district, South Sulawesi. Enfer Clín. 2020;30:141-4. https://doi.org/10.1016/j.enfcli.2020.02.012.

3. World Health Organization. Patient Safety. Geneva: World Health Organization; 2019. Available from: https://www.who.int/ teams/integrated-health-services/patient-safety. [Last accessed on 2021 Mar 31]

4. Casida J, Pinto-Zipp G. Leadership-organizational culture relationship in nursing units of acute care hospitals. Nurs Econ. 2008;26(1):7-15.

PMid: 18389837

5. Tahir M, Amiruddin R, Palutturi S, Rivai F, Saleh LM. The relationship between organizing and leadership style and the quality improvement of primary healthcare services. Enf Clín. 2020;30:39-43. https://doi.org/10.1016/j.enfcli.2019.10.036

6. Burns JM. Transforming Leadership: The Pursuit of Happiness. $1^{\text {st }}$ ed. New York: Atlantic Monthly Press; 2003.

7. McFadden KL, Henagan SC, Gowen CR. The patient safety chain: Transformational leadership's effect on patient safety culture, initiatives, and outcomes. J Oper Manage. 2009;27(5):390-404. https://doi.org/10.1016/j.jom.2009.01.001.

8. Fry LW, Matherly LL, Ouimet JR. The spiritual leadership balanced scorecard business model: The case of the cordon bleu-tomasso corporation. J Manage Spirit Relig. 2010;7(4):283314. https://doi.org/10.1080/14766086.2010.524983

9. Mandriani E, Hardisman H, Yetti H. Analisis Dimensi Budaya Keselamatan Pasien Oleh Petugas Kesehatan di RSUD dr Rasidin Padang Tahun 2018. J Kesehatan Andal. 2019;8(1):1317. https://doi.org/10.25077/jka.v8.i1.p131-137.2019

10. Nordin A. Patient Safety Culture in Hospital Settings. Sweden: Karlstad University Studies; 2015.

11. Moradi Korejan M, Shahbazi H. An analysis of the transformational leadership theory. J Fundam Appl Sci. 2016;8(3):452. https://doi.org/10.4314/jfas.v8i3s.192

12. Nguyen TT, Mia L, Winata L, Chong VK. Effect of transformational-leadership style and management control system on managerial performance. J Bus Res. 2017;70:20213. https://doi.org/10.1016/j.jbusres.2016.08.018

13. Alzahrani S, Hasan AA. Transformational leadership style on nursing job satisfaction amongst nurses in hospital settings: Findings from systematic review. Glob J Health Sci. 2019;11(6):25. https://doi.org/10.5539/gjhs.v11n6p25
14. Kerr R, Garvin J, Heaton N, Boyle E. Emotional intelligence and leadership effectiveness. Leadersh Org Dev J. 2006;27(4):26579. https://doi.org/10.1108/01437730610666028

15. Issah M. Change leadership: The role of emotional intelligence. SAGE Open. 2018;8(3):1-6.

16. Samul J. Spiritual leadership: Meaning in the sustainable workplace. Sustainability. 2019;12(1):267. https://doi. org/10.3390/su12010267

17. Hafsa AM, Maidin A, Palutturi S. Regionalization referral system of the hospital national health insurance. Indian J Public Health Res Dev. 2020;11(3):1422-7.

18. Lammade $\mathrm{AH}$, Hamzah $\mathrm{A}$, Palutturi S. Relationship of marketing mixes with the return interest of patients at ArifinNu'mang hospital. IJPHRD. 2019;10(7):6110. https://doi. org/10.5958/0976-5506.2019.01728.5

19. Shnoda AW, Mohammed Adam S, Abdelrazek F. Emotional intelligence and leadership styles of head nurses at governmental hospitals in port-said. Port Said Sci J Nurs. 2016;3(2):80-101. https://doi.org/10.21608/pssjn.2016.32508

20. Abraham J. Emotional intelligence: The context for successfu nursing leadership: A literature review. NCOAJ. 2017;2(6):1604. https://doi.org/10.15406/ncoaj.2017.02.00054

21. Sfantou DF, Laliotis A, Patelarou AE, Sifaki-Pistolla D, Matalliotakis M, Patelarou E. Importance of leadership style towards quality of care measures in healthcare settings: A systematic review. Healthcare (Basel). 2017;5(4):73. https:// doi.org/10.3390/healthcare5040073

PMid:29036901

22. Merrill KC. Leadership style and patient safety: Implications for nurse managers. JONA J Nurs Admin. 2015;45(6):319-24. https://doi.org/10.1097/nna.0000000000000207 PMid:26010281

23. Murray E. Nursing Leadership and Management for Patient Safety and Quality Care. Philadelphia, PA: F. A. Davis Company; 2017.

24. Jahandar P, Tafreshi MZ, Rassouli M, Atashzadeh-Shoorideh F, Kavousi A. Nurses' perspective on spiritual leadership: Aqualitative study based on Fry's spiritual leadership model. Electron Physician. 2017;9(11):5721-31. https://doi.org/10.19082/5721 PMid:29403611

25. Rosen MA, DiazGranados D, Dietz AS, Benishek LE, Thompson D, Pronovost PJ, et al. Teamwork in healthcare: Key discoveries enabling safer, high-quality care. Am Psychol. 2018;73(4):433-50. PMid:29792459

26. Fowlie J, Wood M. The emotional impact of leaders' behaviours. J Eur Ind Train. 2009;33(6):559-72. https://doi. org/10.1108/03090590910974428

27. Wang $\mathrm{CH}$, Anthony $\mathrm{K}$, Kuo NW. The role of head nurse on communication:A social network approach. IJFCC. 2016;5(1):43-6. 